\title{
PENERAPAN PERATURAN PERUNDANG-UNDANGAN YANG MELARANG PENGGUNAAN PRODUK CRYPTOSEBAGAI ALAT PEMBAYARAN MAUPUN SUBYEK KOMODITAS YANG BISA DIPERDAGANGKAN MELALUI BURSA BERJANGKA DI INDONESIA
}

\author{
Derta Rahmanto, S.H., M.Hum \\ Nelly Ulfah Anisariza, S.H., M.H \\ Fakultas Hukum Universitas Yarsi \\ Email : nelly.ulfah@yarsi.ac.id
}

\begin{abstract}
ABSTRAK
Penelitian ini mengkaji legalitas produk crypto berikut produk turunannya, sebagai alat pembayaran/tukar maupun sebagai salah satu bagian dari komoditi berjangka berikut mekanismenya, dikaitkan dengan segala peraturan perundang-undangan yang berlaku sebagai bahan analisisnya. Alhasil, implementasi penegakan hukum terhadap larangan penggunaan produk cryptovideUndang-Undang No. 7 Tahun 2011 tentang Mata Uang, PBI No. 18/40/PBI/2016, PBI No. 19/12/PBI/2017, dan PBI No. 20/6/PBI/2018 masih dalam tahap sosialisasi adanya larangan saja. Berbeda halnya dengan kebolehan untuk menjadikan produk cryptosebagai subyek komoditi yang dapat diperdagangkan di Bursa Berjangka Indonesia sesuai mekanisme sebagaimana terdapat dalam Peraturan Menteri Perdagangan Nomor 99 Tahun 2018 dan Peraturan Badan Pengawas Perdagangan Berjangka Komoditi Nomor 5 Tahun 2019, yang pada dasarnya merupakan pengakuan terhadap produk crypto sebagai benda yang dapat dimiliki/dikuasai atau bahkan diwariskan menurut KUHPerdata.
\end{abstract}

Kata kunci: Produk Cripto, Alat Tukar/Bayar, Subjek Komoditi

\begin{abstract}
This research examines the legality of crypto products and their derivatives, as a means of payment / exchange or as a part of commodity futures and their mechanisms, complete with all applicable laws and regulations as material for analysis. As a result, the implementation of law enforcement against the prohibition on the use of cryptovide products. Law No. 7 of 2011 concerning Currency, PBI No. 18/40 / PBI / 2016, PBI No. 19/12 / PBI / 2017, and PBI No. 20/6 / PBI / 2018 is still in the socialization stage of the ban. In contrast to the ability to make crypto products a subject that can be regulated on the Indonesian Futures Exchange to someone who is in the Minister of Trade Number 99 of 2018 and Regulation of the Commodity Futures Trading Supervisory Agency Number 5 of 2019, which is recognized as recognition of crypto products as objects that are can be owned / controlled or even inherited according to the Civil Code.
\end{abstract}

Keywords: Crypto Products, Exchange / Payment Tool, Commodity Subject 


\section{PENDAHULUAN}

Kemajuan teknologi informasi dan komunikasi telah melahirkan berbagai dampak, baik dampak positif maupun dampak negatif, karena di satu sisi memberikan kontribusi bagi peningkatan kesejahteraan, kemajuan dan peradaban manusia, namun di sisi lain menjadi sarana efektif perbuatan melanggar hukum. Teknologi informasi dan komunikasi juga telah mengubah perilaku dan pola hidup masyarakat secara global, dan menyebabkan dunia menjadi tanpa batas (borderless), serta menimbulkan perubahan di berbagai bidang kehidupan ${ }^{1)}$.

Fenomena menarik terkait terupdate adalah tindakan pemerintah dalam rangka menegakkan ketertiban umum, dan wibawa negara, yang berhubungan dengan kemajuan teknologi informasi dan komunikasi, mengenai hal-hal yang wajib dilakukan, yang dilarang dan yang boleh dilakukan.

Significant dengan adanya larangan dari Bank Indonesia/BI dan Otoritas Jasa Keuangan/OJK bagi masyarakat, menjadikan produk cryptocurrency sebagai alat pembayaran dan kebolehan dari Bappebti, menjadikan produk cryptocurrency sebagai salah satu komoditi yang dapat diperdagangkan di bursa berjangka komoditi.

Perbedaan perlakuan terhadap produk cryptocurrency tersebut, samasama mempunyai dasar pembenar. Bersesuaian dengan berlakunya UndangUndang Nomor 23 Tahun 1999 tentang Bank Indonesia sebagaimana terakhir kali diubah dengan Undang-Undang Nomor 6 Tahun 2009 tentang Penetapan Peraturan Pemerintah Pengganti Undang-Undang Nomor 2 Tahun 2008 tentang Perubahan Kedua Atas Undang-Undang Nomor 23 Tahun 1999 tentang Bank Indonesia Menjadi Undang-Undang, Undang-Undang Nomor 7 Tahun 2011 tentang Mata Uang, Undang-Undang Nomor 32 Tahun 1997 tentang Perdagangan Berjangka komoditi sebagaimana telah diubah oleh UndangUndang Nomor 19 Tahun 2011 tentang Perubahan Atas Undang-Undang Nomor 32 Tahun 1997 tentang Pedagangan Berjangka Komoditi maupun peraturan terkait lain. Sehubungan dengan pelaksanaan kewenangan

\footnotetext{
1)Agus Raharjo, "Cyber Crime Pemahaman dan Upaya Pencegahan Kejahatan Berteknologi", Bandung,Citra Aditya Bakti, 2002,hal. 34.
} 
pembentukan peraturan perundang-undangan, secara atribusi, delegasi maupun sub-delegasi dari badan atau lembaga atau pejabat di lingkungan tersebut, untuk menafsirkan, membuat, dan menetapkan suatu peraturan perundangundangan secara lebih rinci operasional.

Polemik di atas wajar karena undang-undang bukanlah teks yang sudah selesai. Sebagaimana Sudikno Mertokusumo, yang mengemukakan bahwa "hukum pada dasarnya merupakan sistem terbuka, tetapi dalam sistem hukum itu terdapat sistem terbuka dan sistem tertutup ${ }^{2)}$.

Persitiwa di atas menjadi concern peneliti hingga memutuskan memilih judul "Penerapan Peraturan Perundang-Undangan Yang Melarang Penggunaan Produk Cryptocurrency Sebagai Alat Pembayaran Maupun Subyek Komoditas Yang Bisa Diperdagangkan Melalui Bursa Berjangka Di Indonesia" dalam proposal penelitian kali ini, dengan rumusan masalah :

1. Bagaimana bentuk penegakan hukum terkait dengan implementasi norma larangan penggunaan produk crypto sebagai alat pembayaran di Indonesia?

2. Bagaimana legalitas mekanisme perdagangan produk crypto sebagai subyek komoditas yang layak diperdagangkan di bursa berjangka?

\section{METODE PENELITIAN}

Penelitian ini adalah penelitian yuridis normatif, yang menekankan pada data sekunder, menggunakanlibrary study dengan statuta approach atau pendekatan perundang-undangan yang berlaku terkait dengan masalah yang diteliti. Sampling dalam penelitian ini adalah purposive samplingyang tertuju pada lembaga atau badan atau pejabat yang berwenang yang melarang dan yang menyelenggarakan transaksi atas produk cryptocurrency. Sedang, obyek penelitiannya adalah produk cryptocurrencyitu sendiri, seperti Bitcoin.

Data dalam penelitian ini adalah data sekunder, yang mencakup: Bahan HukumPrimer, Bahan hukumsekunder, danBahan Hukum Tertier yang diperoleh melaluiStudi Kepustakaan dan Studi Lapanganyang kemudian

${ }^{2)}$ Sudikno Mertokusumo, “Penemuan Hukum Sebuah Pengantar”, Yogyakarta,1996. 
dianalisa secara deskriptif, dengan berpedoman pada segala peraturan perundang-undangan yang berlaku.

\section{PEMBAHASAN}

Berbagai siaran pers via media online terpercaya dengan Pejabat Bank Indonesia maupun OJK,terkait larangan penggunaan koin kripto sebagai alat pembayaran atau alat tukar (cryptocuurrency). Berdasarkan Undang-Undang No. 7 Tahun 2011 tentang Mata Uang, Peraturan Bank Indonesia (PBI) No. 18/40/PBI/2016 tentang Penyelenggaraan Pemprosesan Transaksi Pembayaran, PBI No. 19/12/PBI/2017 tentang Penyelenggaraan Teknologi Finansial, PBI No. 20/6/PBI/2018 tentang Uang Elektronik, memenuhi definisi hukum'

1. Aristoteles: "Particular law is that which each community lays down and applies to its own members. Universal law is the law of nature" (Hukum tertentu adalah sebuah hukum yang setiap komunitas meletakkan ia sebagai dasar dan mengaplikasikannya kepada anggotanya sendiri. Hukum universal adalah hukum alam).

2. Grotius: "Law is a rule of moral action obliging to that which is right" (Hukum adalah sebuah aturan tindakan moral yang akan membawa kepada apa yang benar).

3. Hobbes: "Where as law, properly is the word of him, that by right had command over others" (Pada dasarnya hukum adalah sebuah kata seseorang, yang dengan haknya, telah memerintah pada yang lain).

4. Phillip S. James: "Law is body of rule for the guidance of human conduct which are imposed upon, and enforced among the members of a given state" (Hukum adalah tubuh bagi aturan agar menjadi petunjuk bagi kelakuan manusia yang mana dipaksakan padanya, dan dipaksakan terhadap ahli dari sebuah negara).

5. Immanuel Kant: "Hukum ialah keseluruhan syarat-syarat yang dengan ini kehendak bebas dari orang yang satu dapat menyesuaikan diri dengan kehendak bebas dari orang yang lain, menuruti peraturan hukum tentang kemerdekaan". 
Berbagai definisi hukum di atasSignificant dengan segenap peraturan terkait, minimal memenuhi: ${ }^{2)}$

1. Mengatur tentang tingkah laku manusia dalam pergaulan masyarakat.

2. Diadakan oleh badan-badan resmi yang berwenang.

3. Bersifat memaksa.

4. Mengandung sanksi tegas bila terjadi pelanggaran.

A. Rupiah Sebagai Alat Pembayaran/Tukar di Indonesia

Terkait isi kaidah sebagaimana terdapat dalam Undang-Undang No. 7 Tahun 2011 tentang Mata Uang [Ket: selanjutnya disingkat UU 7/2011]. Kewajiban, yang pada dasarnya, merupakan perintah bagi segenap pihak yang berada di wilayah NKRI, untukhanya menggunakan rupiah sebagai alat tukar/pembayaran. Bersesuaian dengan pasal 21 ayat (1) UU 7/2011, yang berbunyi "Rupiah wajib digunakan dalam: a setiap transaksi yang mempunyai tujuan pembayaran; $b$. penyelesaian kewajiban lainnya yang harus dipenuhi dengan uang; dana atau c. tansaksi keuangan lainnya, yang dilakukan di wilayah Negara Kesatuan Republik Indonesia". Tanpa terdapat kebolehan untuk menggunakan mata uang lain selain rupiah. Kecuali dalam rangka memenuhi pasal 21 ayat (2) huruf $a$ s.d. $e$.

Kewajiban karena perintah tersebut, bila dilanggar, menurut pasal 33 ayat (1) UU 7/2011, diancam “dipidana dengan pidana kurungan paling lama 1 (satu) tahun dan pidana denda paling banyak Rp. 200.000.000,00 (dua ratus juta rupiah)".

Kebolehan (permittere) menggunakan koin kriptosebagai alat pembayaran/tukar bersifat individual bergantung pada pengetahuan dan kesepakatan antar individu yang bertransaksi untuk sama-sama menjadikan koin kriptosebagai alat bayar/tukar/currency. Tanpa memanfaatkan merchant, store atau lembaga keuangan, bank non bank, sebagai lembaga fiduciary atau intermediary. transaksi demikian, tentu, tidak bersifat massif sepanjang memenuhi ketentuan pasal 1320 KUHPerdata.

B. Pergerakan Nilai Tukar Crypto

${ }^{4}$ Ibid., Hal. 39 
Madura, Jeff dan Fox, setidaknya terdapat 3 (tiga) faktor yang dapat mempengaruhi pergerakan nilai tukar mata uang, yaitu ${ }^{3)}$ :

1. Faktor Fundamental, seperti inflasi, suku bunga, perbedaan relatif pendapatan antar negara, ekpektasi pasar dan intervensi bank sentral.

2. Faktor Teknis, seperti permintaan dan penawaran devisa pada saat tertentu. Apabila ada kelebihan permintaan sementara sementara penawaran tetap maka harga valuta asing akan tetap. Sebaliknya apabila ada kekurangan permintaan sementara penawaran tetap, maka nilai tukar valuta asing akan terapresiasi.

3. Faktor Pasar, seperti rumors atau berita politik yang bersifat insidentil, yang dapat mendorong harga valuta asing naik atau turun secara tajam dalam jangka pendek. Apabila rumors atau berita sudah berlalu, maka nilai tukar kembali normal.

Faktor-faktor inilah, yang tidak dapat dipenuhi oleh cryptocurrency sehingga tidak dapat digolongkan sebagai mata uang fiat, layaknya mata uang suatu negara. Penting diketahui bahwa cryptocurrency dengan berbagai nomenklaturnya itu, bukanlah mata uang fiat, yang naik turunnya harga tidak akan bergantung atau dipengaruhi oleh ekonomi maupun kebijakan suatu negara. Harga dari setiap mata uang digital tersebut sama seperti produk-produk pada umumnya, yaitu tergantung kepada permintaan dan penawaran. Jika banyak orang melakukan permintaan terhadap suatu mata uang tertentu sedangkan penawarnya tidak begitu banyak, maka nilainya akan meningkat ${ }^{4)}$.

Hal senada sesuai hasil wawancara dengan Sdr. Felix Arnold ${ }^{5)}$, Analis GIKM (Grup Inovasi Keuangan Digital dan Pengembangan Keuangan Mikro) OJK, yang mengatakan bahwa cryptocurrency tidak memenuhi 3 (tiga) faktor, seperti faktor fundamental, teknikal dan rumors. Significant dengan soal fluktuatifnya nilai tukar cryptocurrencyy itu sendiri, yang sewaktu-waktu bisa meningkat secara tajam dalam waktu yang singkat.Sebaliknya, bisa menurun secara drastis.Seiring tinggi rendahnya tingkat supply and demand. Tanpa dapat diketahui sebab musabab munculnya supply and demand yang membentuk harga.

${ }^{3)}$ Madura, Jeff., dan Fox, Roland, “International Financial Management". Boston, Cengage Learning, 2011, Hal. 108.

4) Op.Cit.,https://www.finansialku.com/apa-yang-dimaksud-dengan-cryptocurren cy-mata -uang-digital/. Diakses pada tanggal 4 Desember 2018.

${ }^{5)}$ Hasil wawancara dengan Peneliti pada tanggal__oktober 2018 di Otoritas Jasa Keuangan (OJK) 
Karakter lain, yang tidak dimiliki cryptocurrency, adalah mengenai sistem kurs yang dipergunakan yang cenderung bebas mengambang (floating).

C. Koin Kripto Sebagai Alat Pembayaran (Cryptocurrency)

Junanto Herdiawan, yang mendefinisikan cryptocurrency atau mata uang kripto adalah sejenis kas elektronik yang bisa dikirim langsung secara peer-topeer tanpa melalui perantara institusi keuangan, atau bank. Tidak sebagaimana transaksi pada umumnya, yang harus diproses melalui bank, saat mengirimkan dana atau uang ke pihak lain. Teknologi kripto, pembayaran dilakukan tanpa perantara $^{6}$. Berbeda dengan mata uang konvensional yang sehari-hari digunakan, dihubungkan dengan basis yang dipakai untuk melaksanakan transaksi, yang berbasis komputasi.

Penggunaan crytocurrency sebagai alat pembayaran inilah, yang dilarang menurut Undang-Undang No. 7 Tahun 2011 tentang Mata Uang maupun Pasal 34 huruf a PBI Nomor 18/40/PBI/2016. Larangan ini bersesuaian dengan rencana BI yang akan merazia merchant-merchant yang menerima pembayaran memakai wechat pay atau sejenis ${ }^{7)}$. Antisipasi atas penyelidikan BI di Bali sebelumnya, mengenai pemakaian bitcoin sebagai alat pembayaran hingga Bali dikenal sebagai surganya transaksi bitcoin $^{8)}$, dengan bitcoin ATMnya di daerah kuta9).

Rencana tindakan BI tersebut adalah wujud fungsi dan peran pemerintah sebagaimana termaktub Pasal 34 UUD NRI 1945, yang bersifat affirmative action bagi kepentingan warga masyarakat berbentuk regulasi yang bertujuan melindungi (protection) dan mempromosikan (promotion) kesejahteraan rakyat ${ }^{10)}$.

Sejalan dengan rencana BI tersebut adalah "Sidak" (sidang mendadak) yang dilakukan oleh Pemerintah Propinsi Bali, yang mensinyalir "Praktik Curang Jual Murah Paket Wisata ke Bali untuk Turis Tiongkok"11) suatu wujud affirmative action yang bertujuan melindungi penerimaan negara dari aktivitas

\footnotetext{
${ }^{6}$ https://www.kompasiana.com/junantoherdiawan/5a4a286216835f168147ecf2/ bitcoin-dan-fungsiuang?page=all

7)https://www.cnbcindonesia.com/fintech/20181126172749-37-43754/bi-bakal-s ikat-habis-merchantyang-terima-wechat-pay.

${ }^{8}$ https://www.voaindonesia.com/a/indonesia-selidiki-penggunaan-bitcoin-di-bali /4214934.html.

93 https://coinatmradar.com/bitcoin atm/311/bitcoin-atm-lamassu-kuta-bali-bitcoi ncoid-infor mationcenter/

${ }^{10)}$ Yuswanto, "Peran Negara Hukum Indonesia Melindungi Rakyatnya Dalam Menyambut Masyarakat Ekonomi ASEAN (MEA) 2015", Fiat Justisia Jurnal Ilmu Hukum Volume 8 No. 4, Oktober - Desember 2014, hal. $580-581$.

${ }^{11)}$ https://www.msn.com/id-id/ekonomi/bisnis/ terbongkar- praktik- curang- jual-murah-paket-wisatake-bali-untuk-turis-tiongkok/ar-BBOAsz3.Diakses pada tanggal__ Oktober 2018.
} 
tourism.Equivalent dengan terciptanya ketersediaan lapangan kerja dan meningkatnya penjualan produk lokal, yang berujung pada peningkatan kesejahteraan hidup masyarakat sekitar, yang tidak akan terpenuhi bila praktek curang serupa dibiarkan.

D. Koin Kripto Menurut KUH Perdata

1. Koin Kripto Sebagai Benda/Barang

Pasal 499 KUHPerdata, menurut undang-undang, benda (zaken) adalah tiap barang (goederen) dan tiap hak (rechten) yang dapat menjadi obyek dari hak milik $^{12)}$, yang menurut ilmu hukum, PNH Simanjuntak, dalam bukunya "Hukum Perdata Indonesia", diartikan sebagai segala sesuatu yang dapat menjadi obyek hukum dan barang-barang yang dapat menjadi milik serta hak setiap orang yang dilindungi oleh hukum ${ }^{13)}$.Pun, zaak sendiri tidak selalu diartikan sebagai benda berwujud/bertubuh (lichamelijk zaken), tetapi bisa diartikan juga sebagai benda tidak berwujud/tidak bertubuh (onlichamelijk zaken) menurut Pasal 503 KUHPer ${ }^{14)}$, seperti suatu "objek hukum" (pasal 500 KUH Per), "kepentingan" (Pasal 1354 KUH Per), "kenyataan hukum” (Pasal 1263 KUH Per), “perbuatan hukum" ( Pasal 1792 KUH Per) ${ }^{15}$.

Ambiguitas mengenai apakah koin kripto memenuhi klasifikasi sebagai benda atau tidak. Akibat belum adanya ketentuan undang-undang yang secara khas mengaturnya ${ }^{16)}$. Dijawab dengan berlakunya UU No. 11 Tahun 2014 Tentang Perdagangan Berjangka Komoditi, yang Pasal 1 angka 2-nya menyatakan bahwa "komoditi adalah semua barang, jasa, hak dan kepentingan lainnya, dan setiap derivatif dari Komoditi, yang dapat diperdagangkan dan menjadi subjek Kontrak Berjangka, Kontrak Derivatif Syariah, dan/atau Kontrak Derivatif lainnya". Tidak sebagaimana undang-undang UU No. 32 Tahun 1997 tentang Perdagangan Berjangka Komoditi, yang pada Pasal 1 angka 2-nya mengatur secara "membabi buta" tentang yang dimaksud dengan Komoditi itu, yang secara leterlijk meliputi “...barang dagangan yang menjadi subjek Kontrak Berjangka

\footnotetext{
${ }^{12)}$ R. Subekti, R. Tjitrosudibio, “Kitab Undang Undang Hukum Perdata”, Terjemahan, PT.Pradnya Paramita, Jakarta, 1999, hal.

13)PNH Simanjuntak, "Fukum Perdata Indonesia", Edisi Pertama, Cet. Ke-3, Kencana, 2015, hal. 176.

${ }^{14)}$ Sri Soedewi MMasjchoen Sofwan, "Hukum Perdata: Hukum Benda", Cet.Pertama, Liberty, Yogyakarta, 2000, hal. 19.

${ }^{15)}$ PNH Simanjuntak, Op.Cit., Hal. 177.

16)Frieda Husni Hasbullah."Hukum Kebendaan Perdata: Hak-Hak Yang Memberi Kenikmatan”, IndHil-Co, 2005, hal. 44 - 45.
} 
yang diperdagangkan di Bursa Berjangka”. Suatu pengertian yang bersifat ekstensif, tanpa secara seksama, menentukan "barang dagangan” apa saja yang menjadi ruang lingkupnya. Dikaitkan dengan pengertian barang, berwujud tidaknya atau bahkan bergerak tidaknya, menurut KUHPerdata.

Mengenai keabsahan informasi elektronik itu sendiri, sebagai telah memenuhi Pasal 5 ayat (3) UU ITE atau belum ${ }^{17)}$. Dikaitkan dengan telah diakomodirnya koin kripto sebagai subjek komoditi seakan menafikan tidak adanya sistem registrasi yang membuat tanda tangan digital nirsangkal sehingga teknologi bitcoin, tidak memenuhi syarat PP PSTE sebagaimana pendapat Aby Haryono, dalam tulisannya yang berjudul “Analisis Yuridis Bitcoin Menurut Peraturan Perundang-Undangan Di Indonesia"18). Suatu keadaan yang diharapkan dapat dijawab dengan berlakunya Peraturan Badan Pengawas Perdagangan Berjangka Komoditi Nomor 5 Tahun 2019 tentang Ketentuan Teknis Penyelenggaraan Pasar Fisik Aset Kripto (Crypto Asset) Di Bursa Berjangka, mengikuti perkembangan teknologi kriptografi itu sendiri yang berkembang sedemikian pesat.

\section{Bezit Atas Koin Kripto}

Bezit adalah suatu keadaan memegang atau menikmati sesuatu benda di mana seorang menguasainya baik sendiri ataupun dengan perantaraan orang lain seolah-olah itu adalah kepunyaan sendiri ${ }^{19)}$. Tidak soal apakah bezit atas benda tersebutdiperoleh secara jujur (bezit te goeder trouw) (Pasal 531 KUH Per) atau tidak jujur (bezit te kwader trouw) (Pasal 532 KUH Per), sepanjang "kejujuran" itu tidak dapat dibuktikan sebaliknya (Pasal 533 KUH Per). Demikian itu merupakan konsekuensi logis berlakunya asas "kejujuran", yang selalu ada pada setiap orang ${ }^{20)}$. Bezit atas koinkripto, selain dapat diperoleh dengan cara menambang (mining), dapat juga diperoleh dengan cara melakukan registrasi secara online. Terdapat 2 (dua) cara untuk membuktikan adanya bezit atas koin kripto $^{21)}$ :

\footnotetext{
${ }^{17)}$ Ibid., Hal. 4.

18)Ibid., Hal. 14.

${ }^{19}$ Sri Soedewi Masjchoen Sofwan, "Hukum Perdata: Hukum Benda”, Yogyakarta, Liberty, 1981, Hal.

20) PNH Simanjuntak, Op.Cit., Hal. 185.

${ }^{21)} \mathrm{https} / / /$ cryptocoinindo.blogspot.com/2015/01/membuat-menggunakan-wallet-bitcoin.html.
} 63. 
1. Address

2. Wallet dengan address.

Untuk dapat mengakses wallet, calon user/pengguna, terlebih dulu harus menginstall program (software) wallet ke dalam sistem komputer, berupa personal computer/pc maupun mobilephone dengan fasilitas android, dengan cara situs-situs yang menyediakan pembuatan wallet. Saat ini, sebagian besar dompet (wallet) yang beredar, tidak lagi memberikan private key dalam bentuk rentetan huruf dan angka, namun sudah disederhanakan menjadi security passphrase yang biasanya berbentuk 12 huruf yang mudah untuk dituliskan ataupun diingat. Contoh private key yang sudah diubah menjadi security passphrase: blue spear hotel falcon baseball unique keyboard albino refrigerator twelve field river ${ }^{22}$.

Masih berpotensi menimbulkan dispute ke depannya, dalam hal kepemilikan atas koin kripto itu diperoleh dengan menhackwallet ${ }^{23)}$, token ${ }^{24)}$ atau koin $^{25)}$ dengan address atau tanpa address pemilik asset/koin kripto terdaftar. Bergantung pada daya tahan Pengelola Tempat Penyimpanan Aset Kripto terhadap "gempuran" para miners atau hacker, yang selalu berupaya memperoleh koin kripto secara tidak jujur, yang setiap saat dapat saja terjadi. Sedang akses terhadap buku besar.

\section{Koin Kripto Sebagai Aset}

Aset menurut KBBI adalah sesuatu yang mempunyai nilai tukar ${ }^{26)}$.Cellum $G M B H$, suatu perusahaan yang bergerak di bidang Digital Asset Management mengartikan aset digital sebagai,

“... a term that can cause confusion: traditionally, the word 'asset' is associated with financial assets such as shares, property or policies. It's often used in the world of finance. Digital assets, however, are usually files such as

22)https://blog.indodax.com/bagaimana-cara-mengamankan-dompet-bitcoin/.

23) Wallet adalah media yang dipergunakan untuk menyimpan aset kripto baik berupa koin atau tokenvide Bab I Pasal 1 angka 12 Peraturan Badan Pengawas Perdagangan Berjangka Komoditi Nomor 5 Tahun 2019 Tentang Ketentuan Teknis Penyelenggaraan Pasar Fisik Aset Kripto (Crypto Asset) Di Bursa Berjangka.

${ }^{24)}$ Token adalah salah satu bentuk Aset Kripto yang dibuat sebagai produk turunan dari koinvide Bab I Pasal 1 angka 13 Peraturan Badan Pengawas Perdagangan Berjangka Komoditi Nomor 5 Tahun 2019 Tentang Ketentuan Teknis Penyelenggaraan Pasar Fisik Aset Kripto (Crypto Asset) Di Bursa Berjangka.

${ }^{25)}$ Koin adalah salah satu bentuk Aset Kripto yang memiliki konfigurasi blockchain tersendiri dan memiliki karakteristik seperti Aset Kripto yang muncul pertama kali yaitu bitcoinvide Bab I Pasal 1 angka 14 Peraturan Badan Pengawas Perdagangan Berjangka Komoditi Nomor 5 Tahun 2019 Tentang Ketentuan Teknis Penyelenggaraan Pasar Fisik Aset Kripto (Crypto Asset) Di Bursa Berjangka.

${ }^{26)}$ https://kbbi.web.id/aset.Diakses pada tanggal 29 November 2018. 
images, video or presentations that are valuable to a company. The difference: digital assets contain information. Each and every company produces a lot of information. But information is only useful when it's available to authorized users at all times. "27)

Coin kripto seperti Bitcoin dan Litecoin pada awalnya dibuat dan dirancang untuk digunakan sebagai mata uang yang diprediksi mampu mengganti uang tunai di masa depan, sementara aset digital, di sisi lain, memiliki tujuan yang lebih besar ketimbang sebagai alat pembayaran ${ }^{28)}$. Di situs Technopedia, aset digital diartikan sebagai:

"A digital asset is any text or media that is formatted into a binary source and includes the right to use it; digital files that do not include this right are not considered digital assets. Digital assets are categorized into images and multimedia, called media assets, and textual content ${ }^{29)}$.

Pemerintah, selain BI - OJK, secara khusus, melalui Kementerian Perdagagan RI, pertanggal 02 Oktober 2018, telah mengakui koin kripto sebagai aset vide Pasal 1 Permendag No. 99 Tahun 2018 tentang Kebijakan Umum Penyelenggaraan Perdagangan Berjangka Aset Kripto, yang berbunyi "aset kripto ditetapkan sebagai komoditi yang dapat dijadikan subjek kontrak berjangka yang diperdagangkan di bursa berjangka".

\section{E. Mekanisme Perdagangan Subjek Komoditi di Bursa Berjangka}

Belum diketahui detail pengaturan Bappebti mengenai prosedur dan mekanisme perdagangan cryptocurrencies sebagai subjek komoditi. Berbanding lurus dengan telah diakuinya, cryptocurrencies, sebagai subjek komoditi oleh Bappebti sebagaimana dilansir jauh-jauh hari sebelumnya. Peristiwa ini menarik perhatian Penulis untuk mengetahuinya secara detail. Sayangnya, rencana pelaksanaan interview tidak terlaksana, mengingat pengaturan koin kripto sebagai

${ }^{27)}$ https://www.celum.com/en/what-are-digital-assets.Diakses pada tanggal 29 November 2018.

${ }^{28)} \mathrm{https}$ ://www.duniafintech.com/mengenal-aset-digital-mata-uang-virtual/.Diaks es pada tanggal 29 November 2018.

${ }^{29)} \mathrm{https}$ ://www.techopedia.com/definition/23367/digital-asset.Diakses pada tanggal 29 November 2018. 
subjek komoditi dimaksud masih dalam proses pematangan ${ }^{30)}$. Meskipun cryptocurrencies telah diakui Bappebti jauh-jauh sebelumnya.

Significant dengan mekanisme perdagangan subjek komoditi di Bursa Berjangka, setidak-tidaknya, dikenal 2 (dua) jenis mekanisme perdagangan:

\section{Multilateral ${ }^{31)}$}

Adalah suatu mekanisme perdagangan yang dilakukan di dalam bursa antara banyak pihak (banyak penjual dan banyak pembeli), di mana antara penjual dan pembeli tidak saling mengenal satu dengan yang lainnya.

Produk multilateral, diantaranya ${ }^{32)}$ :

1. JFX (Jakarta Future Echange):

2. ICDX (Indonesia Commodity and Derivatives Exchange):

2. Bilateral ${ }^{33)}$

Adalah suatu mekanisme perdagangan yang dilakukan oleh satu pihak dengan satu pihak yang lain dan biasanya terjadi di luar bursa atau dikenal dengan istilah over-the-counter (OTC). Mekanisme perdagangan ini telah diatur di dalam Undang-Undang No.10 Tahun 2011, yang didefinisikan dengan istilah Sistem Perdagangan Alternatif (SPA).

Belum diperoleh kepastian mengenai dijadikan atau tidaknya koin kripto sebagai salah satu bagian dari produk multilateral, atau merupakan bagian dari Kontrak berjangka Komoditas(commodity futures) yang bersifat bilateral. Di tengah ketidakpastian itu, keduanya memerlukan underlying asset (aset acuan) sebagaimana subjek komoditi lain yang telah dikenal sebelumnya, barang-barang pertanian seperti kopi, gula, kentang misalnya atau sumber daya alam, seperti emas dan minyak. Khusus koin kripto, maka asset acuan atau underlying asset adalah coin dalam bentuk kripto itu sendiri.

\footnotetext{
${ }^{30} \mathrm{https} / /$ www.cnbcindonesia.com/fintech/20181127124147-37-43863/bappebti-matangkan-aturanperdagangan-bitcoin-cs.Diakses pada tanggal 29 November 2018.

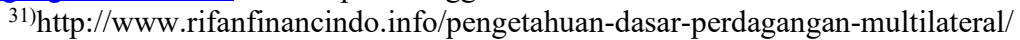

${ }^{32} \mathrm{https}$ ://www.cfforex.com/wp-content/uploads/2018/05/MekanismeTransaksi-PerdaganganBerjangka.pdf.Diakses tanggal 30 November 2018.

33) Op.Cit,.
} 
Termasuk mengenai diadopsi atau tidaknya cara kerja atau mekanisme perdagangan koin kripto sebagaimana masih berlaku hingga saat ini. Terakhir, memiliki tingkat kesulitan tersendiri. Mengingat kemungkinan, tidak bersedianya pemilik akun memberikan akses atas akunnya kepada otoritas atau pengelola fisik pasar, kecuali membangun market place tersendiri. Tanpa perlu membuat nomenklatur koin baru, dengan tetap memakai teknologi blockchain dengan walletnya.

Background materialsnya adalah guna menjamin harga koin kripto tidak terkena penurunan drastis, dilihat dari sisi penjual. Dari sisi pembeli, diharapkan tidak menimbulkan kerugian jika terjadi kenaikan. Melindungi atau menguntungkan pembeli/investor akibat kenaikan harga. Meski tidak selalu demikian. Mengingat banyaknya faktor yang dapat mempengaruhi tingkat harga acuan/reference price.

"Tulip Mania" adalah metafor yang dapat dijadikan sebagai acuan bila terjadi gelembung ekonomi yang besar atas suatu produk komoditi, ketika harga aset menyimpang dari nilai-nilai intrinsiknya ${ }^{34)}$. Metafor sejenis, baiknya, diantisipasi oleh Bappebti, dalam merancang prosedur maupun mekanisme perdagangan tersebut.

Mengingat cryptocurrency sebagai teknologi mata uang virtual, yang menggunakan sistem kriptografi untuk mengamankan transaksinya. Tidak seperti mata uang yang setiap hari dipergunakan.Cryptocurrency tidak berbentuk fisik karena memang hanya ada di dunia virtual atau berbentuk digital. Suatu karakter unik, yang untuk saat ini, hanya dimiliki cryptocurrencies, berbeda dengan subjek komoditi lain.

Karenanya adalah tidak mungkin menjadikan cryptocurrency sebagai produk multilateral mengingat larangan BI dan OJK untuk menjadikannya sebagai alat bayar. Pun tidak semua negara mempekenankannya, berlaku sebagai sebagai alat bayar. Selain mata uang masing-masing negara tersebut belum lagi mengenai price referencenya yang tidak terkendali akibat penguasaan hanya terjadi pada satu dua investor dengan super computernya, yang notabene bisa mengakibatkan

\footnotetext{
${ }^{34}$ https://id.wikipedia.org/wiki/Tulip mania.Diakses tanggal 30 November 2018. Mengutip dari French, Doug (2006), "The Dutch monetary environment during tulipomania" (PDF), The Quarterly Journal of Austrian Economics, 9 (1): 3 -14, doi:10.1007/s12113-006-1000-6. Retrieved on June 24, 2008.
} 
kenaikan harga secara fluktuatif oleh fiktif investor, tanpa ada supply and demand.

Kecuali mengenai harga acuan yang tetap bergantung pada tinggi rendahnya tingkat supply and demand. Suatu tingkat supply and demand yang bisa saja merupakan akibat penambangan (mining) yang dilakukan oleh segelintir orang, yang berpotensi menimbulkan pergerakan nilai secara tidak sebenarnya tanpa terdapat suatu alasan yang bersifat fundamental.

Karakter lainpasar cryptocurrency yang perlu diwaspadai dan diatur secara cukup oleh Bappebti, diantaranya mengenai ${ }^{35)}$.

1. Adanya potensi tingkat perubahan (volatilitas) dan fluktuasi yang sangat cepat berubah dan ekstrem, bahkan dalam waktu beberapa jam saja suatu koin kripto dapat mencapai kenaikan harga sampai dengan 1000\%;

2. Dibutuhkan sebuah sistem untuk mencegah setiap bentuk perbuatan curang atau penyalahgunaan jaringan.

3. Perlunya pembatasan bagi miners untuk menambahkan transaksi cryptocurrency ke dalam sistem yang secara otomatis akan memberikan sejumlah koin kepadanya. Sebagai satu-satunya caravalid untuk menghasilkan koin "baru", yang dapat dihasilkan dari proses seorang penambang berhasil memecahkan teka-teki kriptologi.

Tiga hal yang diserahkan oleh Bapebti kepada Bursa Berjangka, Lembaga Kliring Berjangka dan Lembaga Penjaminan Berjangka, Anggota Lembaga Kliring dan Penjaminan Berjangka, Pedagang Fisik Kripto, Pengelola Tempat Penyimpanan Aset Kripto untuk memenuhinya. Bersesuaian dengan Peraturan Badan Pengawas Perdagangan Berjangka Komoditi Nomor 5 Tahun 2019 Tentang Ketentuan Teknis Penyelenggaraan Pasar Fisik Aset Kripto (Crypto Asset) Di Bursa Berjangka, yang diantaranya mengatur bahwa aset kripto yang dapat diperdagangkan adalah asset:

a. berbasis distributed ledger technology;

b. berupa Aset Kripto utilitas (utilty crypto) atau Aset Kripto beragun aset (Crypto Backed Asset);

${ }^{35)}$ Op.Cit.,https://www.finansialku.com/apa-yang-dimaksud-dengan-cryptocurre digital/. Diakses tanggal 4 Desember 2018.

ncy-mata-uang- 
c. nilai kapitalisasi pasar (market cap) masuk ke dalam peringkat 500 (lima ratus) besar kapitalisasi pasar Aset Kripto (coinmarketcap) untuk Kripto Aset utilitas;

d. masuk dalam transaksi bursa Aset Kripto terbesar di dunia;

e. memiliki manfaat eknomi, seperti perpajakan, menumbuhkan industri informatika dan

f. kompetensi tenaga ahli dibidang informatika (digital talent); dan telah dilakukan penilaian risikonya, termasuk risiko pencucian uang dan pendanaan terorisme serta proliferasi senjata pemusnah massal, yang perdagangannya harus memperhatikan:

a. prinsip-prinsip tata kelola perusahaan yang baik dengan mengedepankan kepentingan Anggota Bursa Berjangka, Pedagang Fisik Aset kripto, dan Pelanggan Aset Kripto untuk memperoleh harga yang wajar dan sesuai;

b. tujuan pembentukan Pasar Fisik Aset Kripto sebagai sarana pembentukan harga yang transparan dan penyediaan sarana serah terima fisik, serta dipergunakan sebagai referensi harga di Bursa Berjangka;

b. kepastian hukum;

c. perlindungan Pelanggan Aset Kripto; dan

d. memfasilitasi inovasi, pertumbuhan, dan perkembangan kegiatan usaha perdagangan fisik Aset Kripto, dengan Bursa Berjangka yang harus memenuhi persyaratan seperti:

a. memiliki modal disetor paling sedikitRp1.500.000.000.000,00 (satu triliun lima ratusmiliar rupiah);

b. mempertahankan saldo modal akhir paling sedikit Rp1.200.000.000.000,00 (satu triliun dua ratus miliar rupiah); dan

c. memiliki paling sedikit 3 (tiga) pegawai yang bersertifikasi Certified Information Systems SecurityProfessional (CISSP), yang Lembaga Kliring Berjangkanya harus memenuhi persyaratan:

a. memiliki modal disetor paling sedikit Rp1.500.000.000.000,00 (satu triliun lima ratus miliar rupiah); dan

b. mempertahankan saldo modal akhir paling sedikit Rp1.200.000.000.000,00 (satu triliun dua ratus miliar rupiah), dengan Pedagang Fisik Aset Kripto yang harus memenuhi persyaratan: 
a. memiliki modal disetor paling sedikit Rp1.000.000.000.000,00 (satu triliun rupiah);

b. mempertahankan saldo modal akhir paling sedikit Rp.800.000.000.000,00 (delapan ratus miliar rupiah);

c. memiliki struktur organisasi minimal Divisi Informasi Teknologi, Divisi Audit, Divisi Legal,Divisi Pengaduan Pelanggan Aset Kripto, Divisi Client Support, Divisi Accounting dan Finance;

d. memiliki sistem dan/atau sarana perdagangan online yang dipergunakan untuk memfasilitasi penyelenggaraan Pasar Fisik Aset Kripto yang terhubung dengan Bursa Berjangka dan Lembaga Kliring Berjangka;

e. memiliki standar operasional prosedur (SOP) minimal mengatur tentang pemasaran dan penerimaan Pelanggan Aset Kripto, pelaksanaan transaksi, pengendalian dan pengawasan internal, penyelesaian perselisihan Pelanggan Aset Kripto dan penerapan program anti pencucian uang dan pencegahan pendanaan terorisme serta proliferasi senjata pemusnah massal; dan

f. memiliki paling sedikit 1 (satu) pegawai yang bersertifikasi Certified Information System Security Professional (CISSP).

Berbagai pengaturan yang sepintas lalu bersifat komprehensif karena ditujukan bagi peningkatan penjaminan dan penyelesaian dari otoritas, seperti Bappebti, Lembaga Kliring dan Penjaminan Berjangka atau penyelenggara Bursa bahwa penjual/pemilik coin tidak gagal serah. Artinya otoritas harus membuat wallet sendiri atau setidak-tidaknya memilik hak untuk dapat mengeksekusi wallet, yang apapun bentuk hak tersebut, yang akun keduanya harus bersifat segregated. Hal inilah yang ditengarai, belum dapat diterima oleh sebagaian kalangan pemilik cryptocurrency. Suatu hal yang mau tidak mau harus dilakukan bila diperdagangkan di bursa berjangka, namun belum menyentuh pada price referenceyang terbentuk dan berlaku di bursa berjangka itu sendiri. Bukan harga di luar bursa, termasuk belum adanya pengaturan tentang syarat pengakuan terhadap kepemilikan teknologi blockchain yang dipergunakan untuk menghasilkan koinitu. Meskipun tidak bersifat 
mutlak.mengingat teknologi tersebut melekat dengan wallet. Suatu teknologi yang terbukti diakui kegunaan dan kecanggihannya, layaknya ledger dalam akutansi.

\section{KESIMPULAN}

1. Terdapat beberapa merchant yang menerima pembayaran menggunakan wechat pay atau virtual currency sejenis a contrario dengan larangan penggunaan koin kripto sebagai alat tukar/pembayaran (cryptocurrency) sebagaimana diatur dalam Undang-Undang No. 7 Tahun 2011 tentang Mata Uang, Peraturan Bank Indonesia (PBI) No. 18/40/PBI/2016 tentang Penyelenggaraan Pemrosesan Transaksi Pembayaran, PBI No.19/12/PBI/2017 tentang Penyelenggaraan Teknologi Finansial, PBI No. 20/6/PBI/2018 tentang Uang Elektronik. Belum diperoleh data mengenai tindak lanjut berupa pembebanan dan jenis sanksi bagi merchant-merchant pelanggar segenap ketentuan dimuka. Kecuali hanya berupa temuan atau hasil "sidak" saja. Bukan suatu bentuk penegakan hukum dalam arti kongkrit sebagaimana amanah peraturan perundang-undangan.

2. Terbitnya Peraturan Menteri Perdagangan Nomor 99 Tahun 2018 Tentang Kebijakan Umum Penyelenggaraan Perdagangan Berjangka Aset Kripto (Crypto Asset) merupakan landas gerak bagi diakuinyakoin kripto dan virtual currency, seperti bitcoin sebagai subyek komoditi yang layak dan dapat diperdagangkan di Bursa Berjangka di Indonesia, yang legalitas dan mekanisme perdagangannya diatur menurut Peraturan Badan Pengawas Perdagangan Berjangka Komoditi Nomor 5 Tahun 2019 Tentang Ketentuan Teknis Penyelenggaraan Pasar Fisik Aset Kripto (Crypto Asset) Di Bursa Berjangka. Aset Kripto yang layak dijadikan sebagai subyek komoditi yang dapat diperdagangkan di Bursa Berjangka tersebut hanya diperuntukan bagi Aset kripto berbasis a. distributed ledger technology, c.beragun aset (Crypto Backed Asset), d. memiliki coinmarketcap 500, d. masuk dalam transaksi bursa Aset Kripto terbesar di dunia, e. memiliki manfaat secara ekonomis seperti perpajakan, f. menumbuhkan industri informatika dan kompetensi tenaga ahli dibidang informatika (digital talent), dan g. telah dilakukan 
penilaian risikonya, termasuk risiko pencucian uang dan pendanaan terorisme serta proliferasi senjata pemusnah massal. Terakhir dan terpenting adalah ditetapkan oleh Kepala Bappebti dalam daftar Aset Kripto yang diperdagangkan di Pasar Fisik Aset Kripto. Pengaturan mutakhir, termasuk pengaturan mengenai syarat permodalan bagi Pedagang Fisik Aset Kripto, mekanisme perdagangan Aset Kripto, seperti pembukaan rekening dan penyimpanan dana, transaksi Aset Kripto, Penarikan Aset Kripto dan Penarikan Dana, pengenaan sanksi hingga Penyelesaian perselisihan. 


\section{DAFTAR PUSTAKA}

Buku

Agus Raharjo, "Cyber Crime Pemahaman dan Upaya Pencegahan Kejahatan Berteknologi", Bandung,Citra Aditya Bakti, 2002.

Brian Kelly, "The Bitcoin Big Bang (Bagaimana Mata Uang Alternatif Akan Mengubah Dunia)", PT. Elex Media Komputindo, Jakarta, 2018.

Bryan A. Garner, Chief Editor, "Black's Law Dictionary", Ninth Edition, West Publishing Co, 2009.

C.S.T. Kansil, "Pengantar Ilmu Hukum dan Tata Hukum Indonesia”, Jakarta, Balai Pustaka, 1989.

Dima Ankaa Wijaya \& Oscar Darmawan, "Blockchain Dari Bitcoin Untuk Dunia", Admin jasakom.com, 2017.

Frieda Husni Hasbullah. "Hukum Kebendaan Perdata: Hak-Hak Yang Memberi Kenikmatan", Ind-Hil-Co, 2005.

Yuswanto, "Peran Negara Hukum Indonesia Melindungi Rakyatnya Dalam Menyambut Masyarakat Ekonomi ASEAN (MEA) 2015”, Fiat Justisia Jurnal Ilmu Hukum Volume 8 No. 4, Oktober - Desember 2014.

Madura, Jeff., dan Fox, Roland, "International Financial Management". Boston, Cengage Learning, 2011.

PNH Simanjuntak, "Hukum Perdata Indonesia", Edisi Pertama, Cet. Ke-3, Kencana, 2015.

R. Subekti, R. Tjitrosudibio, "Kitab Undang Undang Hukum Perdata”, Terjemahan, PT.Pradnya Paramita, Jakarta, 1999.

Sudikno Mertokusumo, "Penemuan Hukum Sebuah Pengantar", Yogyakarta,1996.

Sri Soedewi MMasjchoen Sofwan, "Hukum Perdata: Hukum Benda", Cet.Pertama, Liberty, Yogyakarta, 2000.

Peraturan Perundang-undangan:

Undang-Undang Nomor 23 Tahun 1999 tentang Bank Indonesia sebagaimana terakhir kali diubah dengan Undang-Undang Nomor 6 Tahun 2009 tentang Penetapan Peraturan Pemerintah Pengganti Undang-Undang Nomor 2 Tahun 2008 tentang Perubahan Kedua Atas Undang-Undang 
Nomor 23 Tahun 1999 tentang Bank Indonesia Menjadi UndangUndang;

Undang-Undang Nomor 7 Tahun 2011 tentang Mata Uang;

Undang-Udang Nomor 32 Tahun 1997 tentang Perdagangan Berjangka komoditi sebagaimana telah diubah oleh Undang-Undang Nomor 19 Tahun 2011 tentang Perubahan Atas Undang-Undang Nomor 32 Tahun 1997 tentang Pedagangan Berjangka Komoditi.

Peraturan BI Nomor 18/40/PBI/2016 Tahun 2016 tentang Penyelenggaraan Pemrosesan Transaksi Pembayaran.

Peraturan BI Nomor 19/12/PBI/2017 tentang Penyelenggaraan Teknologi Finansial.

Peraturan BI Nomor 20/6/PBI/2018 tentang Uang Elektronik.

Peraturan Kepala Badan Pengawas Perdagangan Berjangka Komoditi Nomor 90/BAPPEBTI/PER/10/2011 Tahun 2011 tentang Komoditi yang Dapat Dijadikan Subjek Kontrak Berjangka, Kontrak Derivatif Syariah, dan/atau Kontrak Derivatif Lainnya yang Diperdagangkan Di Bursa Berjangka sebagaimana telah diubah oleh Peraturan Kepala Badan Pengawas Perdagangan Berjangka Komoditi Nomor 94/BAPPEBTI/PER/04/2012 Tahun 2012 tentang Perubahan Atas Peraturan Kepala Badan Pengawas Perdagangan Berjangka Komoditi Nomor 90/Bappebti/Per/10/2011 tentang Komoditi yang Dapat Dijadikan Subjek Kontrak Berjangka, Kontrak Derivatif Syariah, dan/atau Kontrak Derivatif Lainnya yang Diperdagangkan Di Bursa Berjangka kemudian diubah untuk kedua kalinya oleh Peraturan Kepala Badan Pengawas Perdagangan Berjangka Komoditi Nomor 114/BAPPEBTI/PER/12/2014 tentang Perubahan Kedua Atas Peraturan Kepala Badan Pengawas Perdagangan Berjangka Komoditi Nomor : 90/Bappebti/Per/10/2011 tentang Komoditi yang Dapat Dijadikan Subjek Kontrak Berjangka, Kontrak Derivatif Syariah dan/atau Kontrak Derivatif Lainnya yang Diperdagangkan di Bursa Berjangka, dan terakhir diubah oleh Peraturan Kepala Badan Pengawas Perdagangan Berjangka Komoditi Nomor 90/BAPPEBTI/PER/10/2011 Tahun 2011 tentang Komoditi yang Dapat Dijadikan Subjek Kontrak Berjangka, Kontrak Derivatif Syariah, dan/atau Kontrak Derivatif Lainnya yang Diperdagangkan di Bursa Berjangkasebagaimana terkahir kali diubah dengan Peraturan Kepala Badan Pengawas Perdagangan Berjangka Komoditi Nomor 123/BAPPEBTI/PER/08/2015 Tahun 2015 tentang Perubahan Ketiga Atas Peraturan Kepala Badan Pengawas Perdagangan Berjangka Komoditi Nomor 90/Bappebti/Per/10/2011 tentang Komoditi yang Dapat Dijadikan Subjek Kontrak Berjangka, Kontrak Derivatif Syariah, Dan/Atau Kontrak Derivatif Lainnya Yang Diperdagangkan Di Bursa Berjangka. 
Peraturan Kepala Badan Pengawas Perdagangan Berjangka Komoditi Nomor 123/BAPPEBTI/PER/08/2015 tentang Perubahan Ketiga Atas Peraturan Kepala Badan Pengawas Perdagangan Berjangka Komoditi Nomor 90/BAPPEBTI/PER/10/2011 tentang Komoditi yang Dapat Dijadikan Subjek Kontrak Berjangka, Kontrak derivative Syariah, dan/atau Kontrak Derivatif Lainnya Yang Diperdagangkan Di Bursa Berjangka.

Akses Internet

UangKriptoKoreaSelatanDiretasHargaBitcoinTerjunBebas, https://ekonomi.kompas.com/read/2018/06/13/070000926/uang-kriptokorea-selatan-diretas-harga-bitcoin-terjun-bebas. Diakses tanggal 24 Juni 2018.

https://www.finansialku.com/apa-yang-dimaksud-dengan-cryptocurrencymata-uang-digital/.

http://www.academia.edu/7662937/Hermeneutika_Hukum_Penemuan_Hukum _atau_Penafsiran_Hukum

https://sengiernest.wordpress.com/2014/10/05/peran-hakim-dalam-penemuanhukum/

https://www.dw.com/id/gejolak-mata-uang-kripto-bitcoin-yang-bikin-pusing/a42258065 .

https://www.kompasiana.com/junantoherdiawan/5a4a286216835f168147ecf2/b itcoin-dan-fungsi-uang?page=all

https://www.cnbcindonesia.com/fintech/20181126172749-37-43754/bi-bakalsikat-habis-merchant-yang-terima-wechat-pay.

https://www.voaindonesia.com/a/indonesia-selidiki-penggunaan-bitcoin-di-bali /4214934.html.

https://coinatmradar.com/bitcoin_atm/311/bitcoin-atm-lamassu-kuta-balibitcoincoid-infor mation-center/

https://www.msn.com/id-id/ekonomi/bisnis/ terbongkar- praktik- curang- jualmurah-paket-wisata-ke-bali-untuk-turis-tiongkok/ar-BBOAsz3.

https://kbbi.web.id/komoditas.

http://www.lib.ui.ac.id/naskahringkas/2016-06/S55835-

Aby\%20HaryonoAbyHaryono, https://cryptocoinindo.blogspot.com/2015/01/membuat-menggunakanwallet-bitcoin.html. 
https://blog.indodax.com/bagaimana-cara-mengamankan-dompet-bitcoin/.

https://kbbi.web.id/aset.

https://www.celum.com/en/what-are-digital-assets.

https://www.duniafintech.com/mengenal-aset-digital-mata-uang-virtual/. https://www.techopedia.com/definition/23367/digital-asset. https://www.cnbcindonesia.com/fintech/20181127124147-3743863/bappebti-matangkan-aturan-perdagangan-bitcoin-cs.

http://www.rifanfinancindo.info/pengetahuan-dasar-perdagangan-multilateral/ https://www.cfforex.com/wp-content/uploads/2018/05/MekanismeTransaksiPerdagangan-Berjangka.pdf.

https://id.wikipedia.org/wiki/Tulip_mania. 